\title{
NEDD8 Gene
}

National Cancer Institute

\section{Source}

National Cancer Institute. NEDD8 Gene. NCI Thesaurus. Code C95847.

This gene plays a role in protein post-translational modification. 